\title{
Pelaksanaan Pemberian Kredit Pada Bank Nagari Sumatera Barat
}

\author{
Reni, Ratna widayati \\ Akademi keuangan dan perbankan "pembangunan" \\ Reni0404@gmai.com
}

\begin{abstract}
The purpose of this study was to find out how the implementation of giving credit to the Bank Nagari west Sumatra. In analyzing the data, qualitative data analysis was used as a research methods that explained descriptively. The results of the study conclude that in the implementation of lending must go through several prosedures that must be met by customers, namely: credit application, credit analysis, credit approval, credit contract and credit search. arter the signing of the contract, the customer must carry out all agreement, which are binding and cannot be contested.
\end{abstract}

Keywords: credit application, credit analysis, credit approval, credit contract, credit search.

\section{PENDAHULUAN}

Perbankan memiliki peran dalam berjalannya perekonomian dan pemerataan pembangunan ekonomi suatu negara. peran Perbankan tersebut disebabkan oleh adanya fungsi utama Bank (Yunita Selvia, n.d.)

Menurut UU No 10 Tahun 1998 tentang Perbankan pasal 1 ayat 2, Bank adalah lembaga keuangan yang menghimpun dana dari masyarakat berupa simpanan dan menyalurkannya kembali kepada masyarakat dalam bentuk Kredit atau bentuk lainnya dalam rangka meningkatkan taraf hidup rakyat banyak.

Bank adalah badan usaha yang menghimpun dana dari masyarakat berupa simpanan dan menyalurkannya kembali kepada masyarakat dalam bentuk kredit dalam rangka meningkatkan taraf hidup masyarakat (Jeri, 2019)

UU No 10 Tahun 1998 tentang Perbankan pasal 1 ayat 11, Kredit adalah penyediaan uang atau tagihan yang dapat dipersamakan dengan itu, berdasarkan perjanjian antara pihak debitur dengan pihak kreditur, yang mana mewajibkan debitur untuk melunasi hutangnya sesuai dengan perjanjian yang telah disepakati dan disertai dengan bunga.

Kredit adalah penyerahan uang, barang maupun jasa dari pihak satu kepada pihak lainnya dengan kesepakatan bersama, yang diselesaikan dengan jangka waktu tertentu dan disertai adanya bunga (Andrianto, SE, 2020)

Alasan penelitian ini dilakukan adalah untuk mengetahui bagaimana Pelaksanaan Pemberian Kredit pada Bank Nagari Sumatera Barat. dalam pelaksanaannya prosedur pemberian kredit dimulai dari proses permohonan kredit hingga proses pencairan kredit. Yang mana dapat dilihat dari perkembengan pemberian kredit dan perkembangan penerima kredit. 
Untuk itu Bank Nagari Sumatera Barat memberikan pelayanan fasilitas layanan jasa kredit yang disesuaikan dengan kebutuhan financial calon nasabah. Karena tujuan utama Bank tidak hanya untuk meraih keuntungan tetapi juga untuk membantu pengembangan usaha kecil dan mikro melalui Pelaksanaan Pemberian Kredit.

Tabel 1

Perkembangan Penerima Kredit dan Perkembangan Pemberian Kredit Bank Nagari Sumatera Barat

Tahun 2018-2020

\begin{tabular}{cccccc}
\hline No & Tahun & $\begin{array}{c}\text { Jumlah } \\
\text { Nasabah }\end{array}$ & $\begin{array}{c}\text { Naik/ } \\
\text { turun }\end{array}$ & $\begin{array}{c}\text { Jumlah Pemberian } \\
\text { Kredit }\end{array}$ & Naik/turun \\
\hline 1 & 2018 & 130.931 & - & $17.577 .892 .514 .955,20$ & - \\
2 & 2019 & 139.208 & Naik & $18.695 .366 .006 .742,56$ & Naik \\
3 & 2020 & 151.762 & Naik & $19.542 .680 .487 .013,03$ & Naik \\
\hline
\end{tabular}

Sumber: Bank Nagari Sumatera Barat

Berdasarkan tabel 1 diatas diketahui bahwa jumlah penerima kredit dan besarnya jumlah pemberian kredit yang diterima oleh nasabah pada Bank Nagari mengalami kenaikan dari Tahun 2018 sampai dengan Tahun 2020.

Dari pemberian kredit, Bank Nagari akan memperoleh pendapatan dari bunga kredit dan biaya administrasi lainnya. didalam Pelaksanaan Pemberian Kredit, jaminan sangat diutamakan oleh sebuah bank seperti, BPKB atau Sertifikat. Hal tersebut dilakukan untuk mengamankan kepentingan Bank selaku sebagai kreditur. Apabila sewaktu-waktu nasabah tidak sanggup untuk melunasi kewajibannya kepada bank, maka jaminan tersebut dapat dijadikan sebagai alat untuk melunasi hutang nasabah, sebab seorang kreditur tidak dilarang untuk meminta jaminan atas pinjaman yang disalurkannya.

\section{LANDASAN TEORI}

\section{Pengertian Bank}

Bank merupakan lembaga keuangan yang kegiatannya tidak hanya melakukan penghimpunan dana dan penyaluran dana melainkan melainkan juga untuk memberikan berbagai jenis fasilitas serta memberikan kepuasan kebutuhan kredit dengan berbagai cara (Suyatno, 2007)

Menurut UU Perbankan no 10 tahun 1998 pasal 1 ayat 1, bank adalah badan usaha yang menghimpun dana dari masyarakat dalam bentuk simpanan dan menyalurkannya kembali kepada masyarakat dalam bentuk kredit atau dalam bentuk lainnya dalam rangka meningkatkan taraf hidup rakyat banyak.

Perbankan adalah salah satu faktor pendukung dalam perekonomian suatu negara, karena perbankan memiliki fungsi sebagai sebuah perantara antara pihak yang kelebihan dana (surplus unit) dengan pihak yang kekurangan dana (defisit unit) yang didasarkan pada prinsip kepercayaan terhadap bank.

Pada saat melakukan kegiatan penyaluran kredit sangat dimungkinkan dilakukannya sebuah investasi, distibusi, dan konsumsi barang dan jasa, yang diakibatkan oleh kegiatan penghimpunan dan penyaluran dana yang berkaitan dengan kegiatan penggunaan dana. 


\section{Pengertian Kredit}

Adapun pengertian kredit yaitu, sebagai berikut:

Menurut (Suyatno, 2007) kredit adalah suatu penyediaan uang yang dapat dipersamakan dengan sebuah tagihan-tagihan yang sesuai dengan persetujuan antara kreditur dengan debitur.

Menurut (Artorejo, 2018) kredit adalah suatu pembiayaan yang dapat dipersamakan dengan uang atau tagihan yang nilainya dapat ditukarkan dengan uang.

Menurut (Andrianto, 2020) kredit adalah suatu hak untuk menerima pembayaran atau sebuah kewajiban dalam melakukan pembayaran pada waktu yang diminta, dalam penyerahan suatu barang-barang pada watu sekarang.

Oleh karena itu kredit merupakan penyediaan uang atau tagihan yang dapat di persamakan dengan itu, berdasarkan persetujuan antara kreditur dengan debitur, yang mana debitur wajib melunasi hutangnya berdasarkan jangka waktu jatuh tempo dan disertai dengan bunga.

\section{Jenis-Jenis Kredit}

Adapun 5 jenis kredit menurut(Donna Eka Putri, n.d.).) yaitu:

a. Jenis kredit berdasarkan tujuan penggunaannya

1) Kredit konsumtif

Yaitu kredit yang penggunaannya habis untuk memenuhi kebutuhan.

2) Kredit produktif

Yaitu kredit yang penggunaannya untuk meningkatkan usaha, baik produksi, perdagangan maupun investasi. Kredit perdagangan yang pada umumnya bermaksud sebagai utilityof place dari suatu barang.

b. Jenis kredit berdasarkan kegunaannya

1) Kredit modal kerja

Yaitu kredit yang digunakan untuk meningkatkan keperluan produksi pada operasionalnya.

2) Kredit investasi

Yaitu kredit jangka panjang yang digunakan untuk memperluas suatu usaha, membangun usaha baru dan sebagainya.

c. Kredit berdasarkan jangka waktu

1) Kredit jangka panjang

Yaitu kredit yang masa pengembaliannya lebih diatas 3 tahun atau 5 tahun. Yang biasanya kredit ini dipergunakan untuk investasi jangka panjang.

2) Kredit jangka menengah

Yaitu kredit yang jangka waktunya sekitar 1 sampai 3 tahun yang biasanya digunakan untuk investasi.

3) Kredit jangka pendek

Yaitu kredit yang jangka waktu pengembaliannya kurang dari 1 tahun dan biasanya digunakan untuk modal usaha. 
d. Kredit berdasarkan cara pemakaiannya

1) Revolving kredit

Yaitu kredit yang proses penarikannya sama dengan rekening koran bebas yang penggunaannya 1 tahun.

2) Kredit rekening koran bebas

Yaitu seorang debitur yang menerima kreditnya dalam bentuk rekening koran yang diberikan blanko cek selain itu rekening koran pinjaman tersebut diisi berdasarkan besarnya jumlah kredit yang diberikan. Kredit rekening koran sangat terbatas. Sebab terdapat pembatas tertentu bagi nasabah yang melakukan penarikan uang via rekening.

3) Kredit rekening koran aflopend

Yaitu kredit yang penarikannya dilakukan dengan cara sekaligus dengan waktu maksimum penarikannya setelah sepenuhnya digunakan oleh nasabah.

e. Kredit menurut jaminannya

1) Secured loans

Yaitu sistem kredit yang seluruh bank di indonesia menggunakannya, yang pemberian kreditnya tanpa menggunakan jaminan.

2) Unsercured loans

Yaitu pemberian kredit yang tanpa menggunakan jaminan.

\section{Tujuan Kredit}

Menurut (Suyatno, 2007: 14) tujuan utama bank dalam memberikan sebuah kredit adalah untuk melakukan pemberian kredit, adapun tujuan sebuah bank yaitu, sebagai berikut:

a. Mencari suatu keuntungan

Yaitu bank melakukan pemberian kredit untuk mendapatkan keuntungan sebanyak mungkin atas pemberian kredit yang dilakukan, yang mana keuntungan tersebut diperoleh dari bunga kredit yang diterima bank sebagai bentuk balas jasa dan biaya administrasi kredit yang dibebankan kepada debitur.

b. Membantu usaha nasabah atau debitur

Yaitu membantu nasabah yang sedang membutuhkan dana, baik digunakan untuk investasi maupun untuk memulai sebuah usaha baru. Dengan adanya dana tersebut nasabah dapat mengembangkan dan memperluas usaha yang dijalankan.

c. Membantu pemerintah

Yaitu semakin banyak dana yang disalurkan, maka akan semakin banyak pula kucuran dana yang diperoleh pemerintah demi meningkatkan pembangunan diberbagai sektor terutama pada sektor rill.

\section{Fungsi Kredit}

Menurut (Suyatno, 2007:12) menjelaskan beberapa fungsi kredit, sebagai berikut: 
a. Meningkatkan daya guna uang

Yaitu ketika uang yang disalurkan melalui kredit maka uang tersebut akan bersifat aktif. Artinya uang yang disalurkan akan memiliki manfaat untuk menghasilkan barang dan jasa, penggunaan barang dan jasa yang dilakukan melalui transaksi jual beli yang melibatkan uang. Sehingga pada saat melakukan transaksi uang maka akan meningkatkan peredaran uang yang ada pada wilayah tertentu.

b. Meningkatkan peredaran dan lalulintas uang

Yaitu uang yang disalurkan antara satu wilayah dengan wilayah lainnya, yang akan mengakibatkan suatu daerah yang kekurangan uang dapat menerima saluran uang berupa kredit. Sehingga daerah tersebut akan memperoleh pendapatan dari daerah lainnya.

c. Meningkatkan daya guna barang

Yaitu kredit yang diberikan oleh bank akan dapat digunakan untuk mengolah barang menjadi mempunyai daya pakai yang lebih tinggi, sehingga suatu barang akan mempunyai nilai jual dan lebih bermanfaat.

d. Meningkatkan peredaran barang

Yaitu kredit yang dicairkan oleh bank akan dapat melancarkan arus barang yang beredar akan semakin bertambah.

e. Sebagai alat stabilitas ekonomi

Yaitu dengan adanya kredit yang disalurkan maka akan membuat pertambahan jumlah barang yang diperlukan oleh masyarakat. Kredit dapat membantu proses ekspor barang dari dalam negeri keluar negeri, sehingga dapat meningkatkan devisa negara menjadi meningkat.

f. Meningkatkan motif usaha

Yaitu kredit yang diberikan oleh bank kepada nasabah akan memiliki dampak yang sangat besar terhadap motivasi usaha. Dengan adanya motivasi, maka akan dapat meningkatkan atau mengembangkan usaha nasabah.

g. Meningkatkan pendapatan

Yaitu kredit yang disalurkan kepada masyarakat industri atau sektor produksi akan mampu meningkatkan kebutuhan tenaga kerja. Secara keseluruhan penyerapan tenaga kerja akan meningkatkan pendapatan masyarakat umum.

\section{Prinsip-Prinsip Pemberian Kredit}

Sebelum fasilitas kredit diberikan, maka bank harus yakin bahwa kredit yang diberikan akan dikembalikan oleh nasabah, keyakinan tersebut diperoleh dari hasil penilaian kredit untuk menentukan tingkat kelayakan nasabah yang akan diberikan oleh pihak kreditur, dilakukan dengan prinsip 5C, 7P dan 3R.

penilaian kredit dengan prinsip 5c, (Neni Ratno, 1998) yaitu:

a. Character/ Watak

Yaitu suatu keyakinan bahwa sifat atau watak dari calon nasabah yang diberikan kredit benar-benar dapat dipercaya, yang mana tercemin pada latar belakang debitur seperti cara hidup, gaya hidup, keadaan keluarga, kebiasaan dan kedudukan sosialnya. Dari karakter ini pihak kreditur 
akan melihat bagaimana reputasi calon debitur apakah perbah memiliki catatan tidakan kriminal atau kebiasaan buruk tidak melunasi pinjaman.

b. Capacity/ Kapasitas

Yaitu melihat nasabah dari kemampuannya dalam membayar kembali pinjamannya. Yang dapat dilihat dari bagaimana nasabah tersebut menjalankan usahanya atau seberapa besar penghasilan yang diterima tiap bulannya. Jika pihak bank menilai bahwa nasabah tidak memiliki kemampuan cukup untuk membayar kredit, maka besar kemungkinan pengajuan kreditnya akan ditolak.

c. Capital/ Permodalan

Yaitu melihat penggunaan modal nasabah apakah efektif atau tidak, yang mana dapat dilihat dari laporan keuangan (neraca dan laporan laba rugi) sehingga pihak bank dapat melihat bagaimana laporan keuangan dari usaha nasabah untuk kemudian di jadikan acuan apakah memang layak untuk diberikan kredit atau tidak.

d. Collateral/ Agunan

Yaitu adanya jaminan yang diberikan calon nasabah saat mengajukan kredit kepada bank. Yang mana nantinya akan di jadikan jaminan oleh bank apabila nasabah tidak dapat membayar kembali pinjaman tersebut. Oleh karena itu, basarnya jaminan harus melebihi besarnya jumlah pinjaman.

e. Condition of economic / Kondisi Ekonomi

Yaitu kondisi ekonomi baik yang bersifat general atau khusus pada bidang usaha yang dijalankan nasabah. Jika kondisi ekonomi sedang tidak baik atau sektor usaha nasabah tidak menjanjikan, pihak bank akan mempertimbangkan kembali untuk melakukan penyaluran kredit. Hal ini terkait dengan bagaimana kemampuan nasabah dalam melunasi pinjamannya yang dipengaaruhi oleh kondisi ekonomi yang kurang memadai.

Sedangkan penilaian kredit dengan prinsip 7p (Kasmir, 2004) antara lain:

a. Personality

Yaitu menilai nasabah dari segi kepribadiannya atau tingkah lakunya sehari-hari maupun kepribadiannya dimasa lalu seperti, emosi, tingkah laku, tindakan nasabah dalam menghadapi masalah dan cara menyelesaikannya.

b. Party

Yaitu mengklasifikasikan nasabah ke dalam golongan tertentu, berdasarkan modal atau loyalitas dan karakternya.

c. Purpose

Yaitu untuk dapat mengetahui tujuan nasabah dalam mengambil kredit, termasuk jenis kredit yang diinginkan nasabah.

d. Prospect

Yaitu untuk menilai usaha nasabah dimasa yang akan datang apakah akan menjanjikan atau tidak, sebab fasilitas kredit yang diberikan tanpa mempunyai prospect, tidak hanya kreditur yang akan dirugikan namun nasabah sendiri juga akan ikut rugi. 
e. Payment

Merupakan ukuran bagaimana nasabah mengembalikan kredit yang telah diambil atau dari sumber mana saja.

f. Profitability

Yaitu untuk menganalisis bagaimana komponen nasabah dalam mencari laba, diukur dari periode ke priode apakah akan tetap sama atau semakin meningkat.

g. Protection

Yaitu tujuannya adalah bagaimana menjaga kredit yang dikucurkan oleh bank, tetapi melalui suatu perlindungan berupa jaminan barang atau orang atau jaminan asuransi.

Serta penilaian kredit dengan prinsip 3R (Kasmir, 2004) antara lain:

a. Return

Yaitu pembelian atas hasil yang akan dicapai oleh perusahaan debitur setelah dibantu dengan kredit bank, lemahnya ialah apakah hasil tersebut dapat menutup untuk pengembalian pinjamannya bersama dengan itu memungkinkan pula usahanya untuk berkembang terus atau tidak.

b. Repayment

Yaitu dalam hal ini bank harus menilai berapa lama perusahaan pemohon kredit dapat membayar kembali pinjamannya sesuai dengan kemampuan.

c. Risk bearing ability

Yaitu dalam hal ini bank harus mengetahui dan menilai sampat sejauh mana perusahaan pemohon kredit mampu menanggung resiko.

\section{Aspek Kelayakan Pemberian Kredit}

Usaha yang dilakukan nasabah akan dianggap layak apabila memenuhi kriteria (Claudio Yosia Tumbel, 1967) sebagai berikut:

a. Aspek hukum / yuridis

Yaitu menilai legalitas badan usaha nasabah. Penilaian ini dimulai dari keabsahan dan kesempurnaan akte pendirian perusahaan, sehingga dapat diketahui siapa pemiliknya dan besarnya modal yang dimiliki oleh pemilik.

b. Aspek pasar dan pemasaran

Yaitu menilai besar kecilnya permintaan terhadap produk yang dihasilkan sekarang dan dimasa yang akan datang, sehingga dapat diketahui prospek pemasaran produk tersebut.

c. Aspek keuangan

Yaitu menilai sumber-sumber dana yang dimiliki untuk membiayai usaha dan bagaimana penggunaan dana tersebut.

d. Aspek teknis / operasi

Yaitu aspek yang membahas mengenai masalah yang berkaitan dengan produksi, lokasi dan lay out, seperti kapasitas mesin yang dimiliki.

e. Aspek manajemen

Yaitu menilai struktur organisasi perusahaan, sumber daya manusia yang dimiliki dan latar belakang yang dimiliki serta pengalaman kerja 
sumber daya manusianya. Pengalaman perusahaan dalam mengelola berbagai proyek yang ada juga menjadi pertimbangan penting.

f. Aspek sosial / ekonomi

Yaitu mengalisis dampak yang ditimbulkan akibat adanya proyek terhadap perekonomian masyarakat dan sosial masyarakat secara umum, sebab kondisi sosial / ekonomi masyarakat akan memberi pengaruh terhadap perkembangan perusahaan.

g. Aspek analisis mengenai dampak lingkungan (AMDAL)

Yaitu analisis ini dilakukan secara mendalam sebelum kredit tersebut disalurkan kepada calon nasabah, sehingga usaha yang dibiayai tidak akan mengalami pencemaran lingkungan sekitar.

\section{Komite Kredit}

Komite kredit adalah komite operasional yang membantu dewan direksi dalam mengevaluasi dan memutuskan permohonan kredit untuk jumlah dan jenis kredit yang ditetapkan oleh direksi (Setyawan, 2017) Adapun tugas dari komite kredit adalah sebagai berikut:

a. Meneliti dan menilai permohonan kredit baru yang berjumlah besar.

b. Meneliti dan menilai permohonan perpajangan kredit dan alasan yang mendasari permintaan tersebut.

c. Meneliti dan melakukan penilaian terhadap permohonan kredit calon debitur apakah sudah sesuai dengan kebijakan bank.

d. Meneliti kelengkapan persyaratan permohonan kredit calon debitur.

Sedangkan tugas dari komite kredit sebagai berikut :

a. Merekomendasikan kepada direksi tentang layak atau tidaknya suatu permohonan kredit untuk dicairkan sesuai dengan batas wewenang dan jenis kredit.

b. Mematuhi setiap kebijakan setiap perkreditan yang telah ditetapkan oleh bank itu sendiri maupun aturan perkreditan lainnya.

c. Memberikan keputusan kredit secara independen, objektif, jujur, teliti dan tidak terpengaruh dari pihak-pihak lain.

d. Memberikan rekomendasi kepada pihak direksi terkait permohonan kredit.

\section{Prosedur Pemberian Kredit}

Prosedur pemberian kredit yaitu serangkaian kegiatan yang saling terkait yntuk menyelesaikan suatu pekerjaan yaitu menyalurkan kredit kepada pihak yang membutuhkan dana.

Prosedur pemberian kredit antara lain:

a. Tahap permohonan kredit

Yaitu untuk memperoleh kredit tahap pertama yang dilakukan calon nasabah adalah mengajukan permohonan kredit dengan melampirkan peryaratan yang telah ditentukan oleh pihak bank dan mengisi formilir yang telah disediakan. 
b. Tahap analisis kredit

Yaitu cara untuk memperoleh keyakinan apakah nasabah tersebut mempunyai kemampuan dalam memenuhi kewajibannya kepada pihak pemberi kredit secara tertib, sesuai kesepakatan dengan pihak kreditur. Analisis kredit juga bertujuan agar kredit yang diberikan mampu sesuai dengan sasaran. Prinsip penilaian yang seringkali digunakan oleh pihak bank adalah prinsip 5c.

c. Tahap persetujuan kredit

Yaitu tahap untuk menentukan apakah permohonan kredit disetujui atau tidak, apabila surat permohonan kredit sudah disetujui maka pihak bank akan memberitahukannya melalui surat persetujuan kepada nasabah dengan mencantumkan persyaratan yang harus dipenuhi oleh calon nasabah.

d. Penandatanganan akad

Yaitu setelah disetujuinya permohonan kredit oleh pihak bank, maka nasabah akan menandatangani akad kredit, mengikat jaminan dengan hipotik dan surat perjanjian baik penandatanganan secara langsung maupun melalui notari.

e. Tahap pencairan kredit

Merupakan tahap terakir yang dilakukan oleh nasah setelah dilakukannya penandatanganan akad. Tahap pencairan kredit berupa pembayaran atau pemindah bukuan kedalam rekening nasabah, serta nasabah harus mengisi kwitansi pencairan kredit dihadapan petugas bank.

\section{PEMBAHASAN}

Prosedur Pemberian Kredit Pada PT. Bank Pembangunan Daerah Sumatera Barat (Bank Nagari)

Prosedur pemberian kredit pada PT. Bank Pembangunan Daerah Sumatera Barat (Bank Nagari) sebagai berikut:

a. Permohonan Kredit

Tahap pertama yang dilakukan nasabah adalah mengajukan permohonan kredit kepada bank nagari. Kemidian mengisi formulir yang telah disediakan oleh bank. Dokumen-dokumen yang perlu dilampirkan didalam permohonan kredit, antara lain:

1) Foto copy KTP suami atau istri

2) Foto copy KK

3) Foto copy STNK

4) Foto copy BPKB

5) Foto copy buku KIR (untuk roda 4 jenis angkutan)

6) Kendaraan jaminan dan data asli harus dibawa

Sedangkan jika pengajuan kredit dilakukan oleh perusahaan maka harus melampirkan, sebagai berikut:

1) Profil perusahaan dan kepengurusannya

2) Tujuan dan manfaat kredit

3) Besarnya pinjaman kredit dan jangka waktu perlunasan 
4) Laporan neraca dan laporan laba rugi (3 tahun terakhir)

5) Foto copy sertifikat agunan atau jaminan

6) Tanda daftar perusahaan

b. Analisis kredit

Setelah melengkapi persyaratan dan pengesian data permohonan kredit selesai, maka pihak bank nagari akan melakukan analisis kredit.

Adapun analisis kredit yang digunakan Bank Nagari berpedoman pada prinsip 5c, yaitu:

1) PersetujCharacter (kepribadian)

Untuk melihat kepribadian calon debitur Bank nagari melihatnya melalui hasil wawancara yang telah dilakukan kepada calon debitur, seperti melihat riwayat kredit calon nasabah, perilaku, kejujuran dan ketaatannya dalam memenuhi pembayaran angsuran kreditnya.

2) Capacity (kemampuan)

Untuk melihat kemampuan dari calon debitur bank nagari meliahat melalui penghasilan calon debitur dan memastikan bahwa pihak debitur memiliki sumber penghasilan yang memadai untuk dapat membayar kewajibannya sesuai jangka waktu yang telah disepakati.

3) Capital (modal atau kekayaan)

Untuk tahap ini bank nagari menilai capital calon nasabah melalui kekayaan yang dimiliki oleh calon debitur tersebut, pihak bank tidak akan memberikan kreditnya jika calon debitur tidak memiliki modal sendiri. sehingga pada tahap ini pihak bank dapat menilai apakah calon nasabah layak atau tidak untuk mendapatkan pinjaman, serta seberapa besar kredit yang akan diterima oleh calon debitur.

4) Collateral (jaminan)

Untuk melihat jaminan ini bank nagari melakukan peninjauan langsung kepada objek jaminan untuk membuktikan kebenarannya. Jaminan ini dapat digunakan pihak bank untuk mengatasi resiko kredit bermasalah yang terjadi akibat kegagalan nasabah dalam melunasi angsuran kreditnya, sehingga jaminan yang diberikan oleh pihak debitur tersebut akan dijadikan sebagai alat untuk melunasi hutang kreditnya dengan cara melakukan pelelangan terhadap jaminan tersebut.

5) Condition of economy ( kondisi ekonomi)

Untuk melihat kondisi ekonomi calon nasabah Bank Nagari melihatnya dari jenis usaha yang dilakukan calon debitur apakah menjanjikan atau tidak, sehingga bank nagari nantinya akan mempertimbangkan untuk memberikan pinjaman atau tidaknya kepada calon nasabah.

c. Persetujuan Kredit

Setelah pihak bank melakukan analisis kredit mulai dari tahap permohonan dan analisis kredit kemudian pihak kabid kredit akan memutuskan apakah permohonan kredit diterima atau ditolak. Jika permohonan kredit disetujui maka akan diberitahukan melalui surat oleh pihak bank dan jika permohonan kredit ditolak maka pihak kreditur akan membuatkan surat penolakan atas permohonan kredit dengan 
mencantumkan alasan penolakan kredit serta bank akan mengembalikan seluruh dokumen yang sebelumnya diserahkan kepada pihak bank.

d. Akad Kredit

Perjanjian dua belah pihak antara debitur dan kreditur dalam keputusan pemberian kredit. Perjanjian tersebut bersifat mengikat dan tidak dapat diganggu gugat. Jika nantinya terjadi wanprestasi oleh pihak debitur maka akan dikenakan sanksi sesuai dengan kebijakan bank nagari.

e. Proses Pencairan Kredit

Setelah dilakukannya penandatanganan akad maka barulah nasabah dapat dicairkan kredit, dengan syarat nasabah harus memiliki rekening atau membuka rekening baru dibank tersebut.

\section{Perkembangan Pemberian Kredit dan Penerima Kredit}

a. Perkembangan Pemberian Kredit

Perkembangan pemberian kredit pada Bank Nagari dapat dilihat melalui tabel, sebagi berikut:

Tabel 2

Perkembangan Pemberian Kredit Bank Nagari Sumatera Barat Tahun 2018-2020

(Jutaan)

\begin{tabular}{cll}
\hline Tahun & Jumlah pemberian kredit & Naik/Turun \\
\hline 2018 & $17.577 .892 .514 .955,20$ & - \\
2019 & $18.659 .366 .006 .742,56$ & Naik \\
2020 & $19.542 .680 .487 .013,03$ & Naik
\end{tabular}

Sumber: Bank Nagari Sumatera Barat

Berdasarkan tabel diatas diketahui bahwa jumlah nasabah yang menerima kredit mengalami peningkatan. Pada tahun 2018 perkembangan kredit yang diberikan sebesar Rp.17.577.892.514.955 dan tahun 2019 mengalami peningkatan menjadi Rp.18.659.366.006.742 serta pada tahun 2020 juga mengalami kenaikan yang cukup signifikan sebesar Rp.19.542.680.487.013

dapat disimpulkan bahwa perkembangan pemberian kredit mengalami peningkatan dari tahun ketahun hal ini disebabkan oleh prestasi kinerja keuanga Bank Nagari yang sangat baik dan mampu untuk dapat mengendalikan kredit bermasalah serta menjadi sebuah pencapaian yang sangat baik.

b. Perkembangan Penerima Kredit

Jumlah penerima kredit pada Bank Nagari dapat dilihat pada tabel sebagai berikut:

Tabel 3

Perkembangan Penerima Kredit Bank Nagari Sumatera Barat Tahun 2018-2020

\begin{tabular}{ccc}
\hline Tahun & Jumlah Peminjam & Naik/Turun \\
\hline 2018 & 130.931 & - \\
2019 & 139.208 & Naik \\
2020 & 151.762 & Naik \\
\hline
\end{tabular}

Sumber: Bank Nagari Sumatera Barat 
Berdasarkan tabel diatas dilihat bahwa penerima kredit pada Bank Nagari pada Tahun 2018 berjumlah 130.931 orang. Pada Tahun 2019 penerima kredit mengalami peningkatan sebanyak 139.208 orang. Dan pada Tahun 2020 kembali mengalami peningkatan sebanyak 151.762 orang.

Dilihat dari jumlah debitur yang menerima kredit tahun 2019 mengalami peningkatan sebanyak 139.208 orang, dan pada tahun 2020 jumlah penerima kredit mengalami peningkatan sebanya 151. 762 orang, dari kenaikan jumlah penerima kredit pada Bank Nagari mengalami perkembangan yang sangat baik.

\section{SIMPULAN}

Berdasarkan penjelasan dan pembahasan dari bab-bab sebelumnya tentang pelaksanaan pemberian kredit, maka penulis dapat menyimpulkan sebagai berikut:

1. Pelaksanaan pemberian kredit pada Bank Nagari Sumatera Barat dimulai dari pengajuan permohonan kredit, analisis kredit, persetujuan kredit, akad kredit dan pencairan kredit.

2. Perkembangan pemberian kredit dan penerima kredit pada Bank Nagari dapat dilihat dari jumlah pemberian kredit dan jumlah nasabah tahun 2018 sampai dengan 2020 yang pada dasarnya mengalami peningkatan dengan jumlah pemberian kredit dari Rp.17.577.892.514.955 sampai dengan Rp.19.542.680.487.013 dengan jumlah penerima kredit 130.931 orang sampai dengan 151.762 orang, hal ini disebabkan oleh kinerja bank dalam mengelola keuangannya sehingga menjadi suatu pencapai yang sangat baik bagi Bank Nagari.

\section{UCAPAN TERIMA KASIH}

Terimakasih penulis sampaikan kepada Semua pihah yang telah memberikan dukungan dan bantuannya dalam penyelesaian tugas akhir ini.

\section{DAFTAR PUSTAKA}

Alanshari, F., \& Marlius, D. (2018). Prosedur Pemberian Kredit KPR Pada PT. Bank Tabungan Negara (Persero) TBK Cabang Pembantu Bukittinggi. https://doi.org/10.31227/osf.io/rsfhc

Amelia, L., \& Marlius, D. (2018). Pengendalian Kredit Dalam Upaya Menciptakan Bank Yang Sehat Pada PT. Bank Pembangunan Daerah Sumatera Barat Cabang Utama Padang. https://doi.org/10.31227/osf.io/kpc64

Andrianto, SE, M. A. (2020). Manajemen Kredit. In Q. Media (Ed.), Qiara Media (Fahmi, Issue July). IKAPI No. 237/JTI/2019.

Andrianto. (2020). Manajemen Kredit (Teori dan Konsep Bagi Bank Umum). In Pasuruan: CV. Penerbit Qiara Media.

Asyari, A., \& Marlius, D. (2021). Proses Penyelesaian Kredit Bermasalah Pada PT. BPD Sumatera Barat Cabang Pasar Raya Padang. https://doi.org/10.31219/osf.io/3hfcr 
Claudio Yosia Tumbel. (1967). Aspek-Aspek Penilaian Dalam Pemberian Kredit Bank. Aspek-Aspek Penilaian Dalam Pemberian Kredit, III(3), 44-51.

Widayati, R. (2019). Pelaksanaan Kredit Pada Bank Perkreditan Rakyat LPN Pasar Baru Durian Sawahlunto. https://doi.org/10.17605/OSF.IO/5HPAB

JERI, R. (2019). Pelaksanaan Pemberian Kredit Modal Kerja. Pelaksanaan Pemberian Kredit Modal Kerja.

Kasmir. (2004). Dasar-Dasar Perbankan. raja Grafindo Persada,2004.

Setyawan, A. (2017). Analisis Prosedur Pemberian Kredit Pada Pt. Bank Perkreditan Rakyat Artha Samudera Indonesia Kediri. Analisis Prosedur Pemberian Kredit, 01(08), 14-16.

Suyatno, D. T. (2007). Dasar dasar perkreditan. GramediaEdisi.

Wulandari, N. W. F. (2019). http://www.journals.segce.com/index.php/JSAM. Analisis Faktor-Faktor Yang Mempengaruhi Kolektibilitas Kredit, 1(3), 149.

Yunita Selvia, R. W. (n.d.). Sejahtera Pariaman Yunita Selvia, Ratna Widayati. Pelaksanaan Pemberian Kredit, 1-15. 